\title{
The phenomenon of fluorescence in immunosensors
}

\author{
Aleksandra Kłos-Witkowska \\ Faculty of Mechanical Engineering and Computer Science, Department of Computer Science and Automatics, University of Bielsko-Biala, \\ Bielsko-Biala, Poland
}

The phenomenon of fluorescence in immunosensors is described in this paper. Both structure and characteristics of biosensors and immunosensors are presented. Types of immunosensors and the response of bioreceptor layers to the reaction with analytes as well as measurements of electrochemical, piezoelectric and optical parameters in immunosensors are also presented. In addition, detection techniques used in studies of optical immunosensors based on light-matter interactions (absorbance, reflectance, dispersion, emission) such as: UV/VIS spectroscopy, reflectometric interference spectroscopy (RIfs), surface plasmon resonance (SPR), optical waveguide light-mode spectroscopy (OWLS), fluorescence spectroscopy. The phenomenon of fluorescence in immunosensors and standard configurations of immunoreactions between an antigen and an antibody (direct, competitive, sandwich, displacement) is described. Fluorescence parameters taken into account in analyses and fluorescence detection techniques used in research of immunosensors are presented. Examples of immunosensor applications are given.

Key words: biosensor, immunosensor, fluorescence, absorbance, UV/ Vis

Received: 28 December, 2015; revised: 04 February, 2016; accepted: 10 February, 2016; available on-line: 19 May, 2016

\section{BIOSENSORS AND IMMUNOSENSORS}

Biosensors are one of the greatest challenges in biotechnology, while simultaneously being one of the most promising fields in developing new generation sensors. They offer a fast, selective and sensitive detection of various components such as: pesticides (Meng et al., 2013; Sassolas et al., 2012; Mostafa, 2010), heavy metal ions (Bontidean et al., 2003; Kamtekar et al., 1995; Kulkarni et al., 2011), chemical warfare agents (Burnwotrh et al., 2007), bacteria (Sapsford et al., 2004; Ivnitski et al., 1999), viruses (Nidzworski et al., 2014; Sapsford et al., 2004; Xu et al., 2007), tumor markers (Zhang et al., 2013; Tothill 2009; Soper et al., 2006), cardiac biomarkers (MazherIqbal et al., 2013).

Biosensors find wide applications in medical diagnostics, (Justino et al., 2010), food industry (Leonard et al., 2003), environmental protection (Kłos-Witkowska, 2015), arms industry (Bartoszcze, 2003), agricultural industry (Rana et al., 2010) and biopharmaceutical research (Vo-Dinh \& Cullum, 2000). According to the report (Thusu, 2010), biosensors are used in 47 applications and an increasing number of potential applications is recorded every year. These devices are most frequently used in clinical analyses and medical diagnoses. As defined by the International Union of Pure and Applied
Chemistry (IUPAC 1999) biosensor is a self-contained integrated device capable of proving specific quantitative or semi-quantitative analytical information using elements retained in direct spatial contact with transduction element (Thevenot et al., 1999).

Among a large family of biosensors there are immunosensors that in a sensitive selective receptor layer contain an immobilized biological component (antibody, antigen, hapten) being an immunological receptor for recognition of measurable analyte molecules.

The receptor layer directly contacts the transducer layer where the biological interaction is transformed into a measurable signal (Cruz et al., 2002; Ramirez et al., 2009).

Immunosensors are those biosensors that use a specific reaction between an antibody $(\mathrm{Ab})$ and an antigen (Ag) or small molecules called haptens.

Haptens elicit the production of antibodies only when attached to larger molecules such as proteins.

Antibodies as immune-related proteins are very often referred to as immunoglobulins.

They consist of four polypeptide chains: two heavy and two light chains. They form Y-shaped molecules of molecular weight greater than $1.5 \mathrm{kDa}$. There are two types of light chains: $x$ and $\lambda$ types and five types of heavy chains: $\alpha, \delta, \varepsilon, \gamma, \mu$ types.

Depending on the type of heavy chain present in an antibody, immunoglobulins are divided into five classes of different structure and immunological functions.

Immunoglobulins are used by the immune system to identify and neutralize foreign bodies, and show also binding properties to an antigen.

The types of antibodies and its function as well as references to its comprehensive description are listed in Table 1 and more deeply in the book (Gołab et al., 2013).

The antibody-antigen bonds are the most compatible bonds for selectivity and affinity among all protein bonds (Leckband et al., 2000). However, despite of a high affinity constant $K_{\mathrm{a}}=10^{12}-10^{14}$ (Borisov \& Wolfbeis, 2008) they are not covalent bonds (Reverberi \& Reverberi, 2007).

A high reaction rate, efficiency and affinity constant are a consequence of weak molecular interactions such as: Van der Waals forces, hydrogen bonds, ion-dipole bonds or hydrophobic bonds.

Knowledge of interaction mechanisms is a key for understanding antibody-antigen interactions (Reverberi \&

e-mail: awitkowska@ath.bielsko.pl

Abbreviations: UV/VIS, Ultraviolet-visible spectroscopy; RIfs, reflectometric interference spectroscopy; SPR, surface plasmon resonance; OWLS, optical waveguide light-mode spectroscopy; IUPAC, Union of Pure and Applied Chemistry; $K_{a}$, affinity constant; RNA, ribonucleic acid; DNA, deoxyribonucleic acid; FRET, Fröster resonance energy transfer; ELISA, Enzyme Linked Immune Sorbent Assay) 
Table 1. Types of antibodies and their function

\begin{tabular}{|c|c|c|c|}
\hline No. & Antibodies & Functions & References \\
\hline 1 & $\lg M$ & $\begin{array}{l}\text { they are produced in the initial phase of the immune response to } \\
\text { infection } \\
\text { they recognize viral antigens and bacterial toxins }\end{array}$ & $\begin{array}{l}\text { Quchida et al., } 2012 \\
\text { Kaveri et al., } 2012 \\
\text { Unzu et al., } 2014 \\
\text { Ehrenstein \& Notley, } 2010 \\
\text { Grönwall et al., } 2012\end{array}$ \\
\hline 2 & $\lg G$ & $\begin{array}{l}\text { major antibody of secondary immune responses } \\
\text { neutralizes the bacterial toxins and viruses }\end{array}$ & $\begin{array}{l}\text { Hjelhold et al., } 2013 \\
\text { Vidarson et al., } 2014 \\
\text { Kulshrestha et al., } 2013\end{array}$ \\
\hline 3 & $\lg A$ & $\begin{array}{l}\text { acts as a first line defense against many invading pathogens } \\
\text { key role in immune protection of mucous membranes }\end{array}$ & $\begin{array}{l}\text { Woof \& Kerr, } 2006 \\
\text { Majkowska-Skrobek \& Augustyniak, } 2004 \\
\text { Snoeck et al., } 2006\end{array}$ \\
\hline 4 & $\lg D$ & $\begin{array}{l}\text { role is still incompletely understood } \\
\text { function has been preserved since its ancient origins } \\
\text { function is to signal the } B \text { cells to be activated and afterworld be } \\
\text { ready to take part in the defense of the body in the immune system } \\
\text { expression of lgD may rescue cells undergo programmed cell death }\end{array}$ & $\begin{array}{l}\text { Edholm et al., } 2011 \\
\text { Geisberger et al., } 2006 \\
\text { Guo, } 2010\end{array}$ \\
\hline 5 & $\lg \mathrm{E}$ & $\begin{array}{l}\text { is performed as part of an initial screen for allergies } \\
\text { high IgE levels may indicate a parasitic infection }\end{array}$ & $\begin{array}{l}\text { Amarasekera, } 2011 \\
\text { Chang et al., } 2015 \\
\text { Hamilton et al., } 2010 \\
\text { Nepper-Christensen et al., } 2003 \\
\text { Rosenwasser, } 2011\end{array}$ \\
\hline
\end{tabular}

Reverberi, 2007, Leckband et al., 2000). Such interaction is used in immunosensor design where the receptor layer can contain both antigens and antibodies.

Nevertheless, due to the loss of antibody affinity during the immobilization process, antigens are primarily used in the receptor layer, while antibodies perform the role of analytes (molecules to be detected) (Moina \& Ybarra, 2012). During the detection process the binding of antibodies (Davies et al., 1988).

The mechanism of complex formation is commonly known as lock and key fit (Braden et al., 1995; Griffiths et al., 2014) and more vividly, it can be compared to fitting an appropriate key to the lock, where antibodies and antibodies perform the role of appropriate key and lock, accordingly.

During the complex formation process a signal is generated and the this signal is transformed to be then measured and analyzed with appropriate methods depending on its type. Depending on the type of an input signal, biosensors are divided into the following groups: optical, electrochemical, resistance, piezoelectric, thermometric (Monosik et al., 2012; Bhardwaj et al., 2014; Shruthi et al., 2014). According to the biological material used in the receptor layer we can distinguish enzymatic (containing an enzyme in the matrix), protein (using a protein in the receptor layer), nucleic (using DNA or RNA nucleic acids) biosensors (Korotkaya, 2014; GabigCimińska et al., 2004; Cynk et al., 2012; Gabig-Cimińska et all, 2005; Suzuki et al., 1982) and immunosensors (where an antibody or antigen can be used) (Vo-Dinh et al., 2000). In immunosensors, analyte detection is based on an electrochemical, optical or mass change signal.

The types of immunosensors and receptor layer response to the interaction with analytes under investigation are presented in Fig. 1.

In electrochemical immunosensors the complex formation is indicated by parameter changes: amperage (amperometric immunosensors), potential difference (potentiometric immunosensor), resistance (conductometric immunosensor) (Moina \& Ybarra, 2012). Electrochemical immunosensors were used for detecting protein tu- mor markers (Chikkaveeraiah et al., 2012; Chen et al., 2013; Yang et al., 2011).

Voltammetry and amperometry combined with immunosensors offer a fast, easy and low-cost detection of tumor markers due to a wide range of protein detectability.

A conductometric immunosensor based on magnetic nanoparticles was used for detecting $E$. coli (Hnaiein et al., 2008; Mujika et al., 2009).

However, in piezoelectric immunosensors the resonance frequency of oscillating piezoelectric crystals can be affected by its mass changes (Chen et al., 2011).

This type of sensors was used for detecting antigens of Mycobacterium tuberculosis (Kumar, 2000; Jaramillo et al., 2013).

Special attention should be paid to optical immunosensors that monitor optical changes resulting from the interactions with the analyte. These changes are

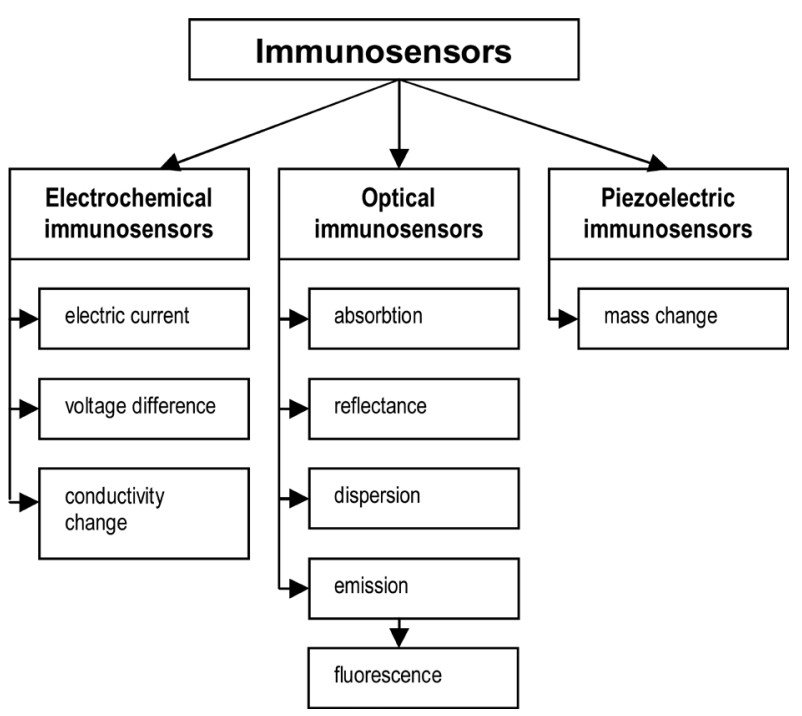

Figure 1. Types of immunosensors and response of bioreceptor layers to the interaction with the target analytes 
Table 2. Mechanisms of light-matter interaction, detections techniques employed in optical immunosensors and its description

\begin{tabular}{|c|c|c|c|c|}
\hline No. & $\begin{array}{l}\text { Mechanism of light- } \\
\text {-matter interaction }\end{array}$ & Detection techniques & Description of methods & Literature \\
\hline 1 & Absorbance & UV/VIS spectroscopy & $\begin{array}{l}\text { This method uses electromagnetic radiation } \\
(200-1100 \mathrm{~nm}) \\
\text { Absorbance changes are caused by the interac- } \\
\text { tion with an analyte } \\
\text { Measurements are made in a transparent me- } \\
\text { dium }\end{array}$ & $\begin{array}{l}\text { Que et al., } 2014 \\
\text { Ying et al., } 2013 \\
\text { Gong et al., } 2009\end{array}$ \\
\hline 2 & Reflectance & $\begin{array}{l}\text { Reflectometric inter- } \\
\text { ference spectroscopy } \\
\text { (RIfS) } \\
\text { Surface plasmon reso- } \\
\text { nance (SPR) }\end{array}$ & $\begin{array}{l}\text { The technique based on white light interference } \\
\text { in thin films } \\
\text { Analyte binding changes the reflection coeffi- } \\
\text { cient, thus directly alters also the product Ln, } \\
\text { where } n \text { - is reflection coefficient and L is film } \\
\text { thickness } \\
\text { The method uses the reflection coefficient of } \\
\text { very thin films of materials absorbed in a metal }\end{array}$ & $\begin{array}{l}\text { Alvarez et al., } 2009 \\
\text { Oh et al., } 2004 \\
\text { Oh et al., } 2003\end{array}$ \\
\hline 3 & Dispersion & $\begin{array}{l}\text { Optical waveguide } \\
\text { light-mode spectrosco- } \\
\text { py (OWLS) }\end{array}$ & $\begin{array}{l}\text { The technique based on measurements of the } \\
\text { resonant polarization angle of laser light scat- } \\
\text { tered from the grating and coupled with a thin } \\
\text { film waveguide } \\
\text { This methods allows the thickness of absorber to } \\
\text { be measured }\end{array}$ & Szekacs et al., 2009 \\
\hline 4 & Emission & $\begin{array}{l}\text { Fluorescence spectro- } \\
\text { scopy }\end{array}$ & $\begin{array}{l}\text { The method for measuring fluorescence intensi- } \\
\text { ty, life time, energy transfer between donor and } \\
\text { acceptor (FRET) }\end{array}$ & $\begin{array}{l}\text { Anderson et al., } 1988 \\
\text { Handbury et al., } 1996 \\
\text { Grand et al., } 2004\end{array}$ \\
\hline
\end{tabular}

caused by light-matter interactions: absorption, reflectance, dispersion or emission (Podbierska, 2011).

Mechanisms of light-matter interactions, detection techniques and its description as well as references are presented in Table 2.

\section{DETECTION METHODS USED IN OPTICAL IMMUNOSENSORS}

Ultraviolet/Visible (UV/VIS) absorption spectroscopy - spectroscopy that enables imaging of electron transitions from the ground state to the excited state in a molecule, that are related to changes in vibrational and rotational energy. The range of electromagnetic spectrum used in this spectroscopy is $200-1100 \mathrm{~nm}$. Measurements are usually made with a transparent medium, while absorbance changes are caused by an analyte.

Absorbance measurements made by employing UV/ VIS spectroscopy were used for developing a new type of immunosensors designed for tracking antibiotic residues (Que et al., 2014).

Ying and coworkers (2013) used this technique to modify amperometric immunosensors during carbofuran detection.

UV/VIS spectroscopy was also used by Gong and collaborators (Gong et al., 2009) in studies of the cyanidin-horseradish peroxidase-hydroperoxide reaction in terms of applications for enzyme-linked immunosensing assays.

Optical waveguide light-mode spectroscopy (OWLS) is a technique based on measurements of the resonant polarization angle of laser light scarred from the grating and coupled with a thin film waveguide.

With this technique it is possible to determine the thickness of the absorber layer (Szekacs et al., 2009).

This method was used to improve low-detection limit immunosensors (compared to traditional immunological tests for detecting: herbicide active ingredient triflualin, fusarium mycotoxin zearalenone, egg yolk protein and vitellogenim (Szekacs A et al., 2009).
One of very sensitive method that uses reflection of light is reflectometric interference spectroscopy (RIfS).

This method is based on white light interference in thin films. Through analyte binding the reflection coefficient from the film is changed, thus also the product $\mathrm{nL}$, where $\mathrm{n}$ is reflection coefficient and $\mathrm{L}$ is film thickness. (Alvarez et al., 2009).

This technique was employed to determine the porous alumina $\left(\mathrm{pAl}_{2} \mathrm{O}_{3}\right)$ film in immunosensors that use simple protein and two antibodies (IgG) (Alvarez et al., 2009).

Surface plasmon resonance (SPR) is an optical technique for measuring reflection coefficient of very thin films of materials absorbed by metals (Pattnaik, 2005).

This method was used in immunosensors by $\mathrm{Oh}$ and collaborators (Oh et al., 2003; Oh et al., 2004) to detect sallmonella typhimurium and legionella pneumophila.

Fluorescence spectroscopy is one of the most common research methods in studies of immunosensors, although this method requires the presence of fluorophores that can be natural or artificial (created by fluorescent labeling of a non-fluorescent molecules).

This technique allows fluorescence intensity, life time, or energy transfer between donor and acceptor (FRET) to be measured.

According to Ramirez (Ramirez et al., 2009), optical immunosensors can be divided into three groups:

a) direct monitoring sensors (without immunoreaction labels),

b) sensors that detect compounds labeled in immunoreactions (fluorescent labeled compounds),

c) sensors that measure products of immunological reactions.

\section{THE PHENOMENON OF FLUORESCENCE IN IMMUNOSENSORS}

Among all detection methods described above, fluorescence is the most commonly used technique.

This results from a high single-molecule sensitivity and immediate response in most cases. 
Table 3. Fluorescence detection methods used in immunosensor studies

\begin{tabular}{|c|c|c|c|}
\hline No. & $\begin{array}{l}\text { Fluorescence detection methods used in } \\
\text { immunosensor study }\end{array}$ & Analyte & References \\
\hline 1 & Fluorescent intensity & rothavirus, poliovirus, variola virus & Jung et al., 2010 \\
\hline 2 & Fluorescent intensity & immunoglobulin G (lgG) & Aoyagi \& Kudo, 2005 \\
\hline 3 & Fluorescent intensity & coplanar polychlorinated biphenyls & Endo et al., 2005 \\
\hline 4 & Fluorescent intensity & cancer biomarker prostate specific antigen (PSA). & Zhu et al., 2014 \\
\hline 5 & Fluorescent intensity & cardiac biomarker & Matveeva et al., 2004 \\
\hline 6 & Fluorescent intensity & tumor marker & Lee et al., 2010 \\
\hline 7 & FRET & pathogenic bacteria & Hejduk \& Hejduk, 2010 \\
\hline 8 & FRET & salmonella typhimurium & Ko \& Grant, 2006 \\
\hline 9 & FRET & albumin concentrations in saliva, urine and serum & Wang et al., 2012 \\
\hline 10 & Time Resolved Fluorescence & ricin & Huang et al., 2015 \\
\hline
\end{tabular}

This method is more often used than absorption methods because the detectable analyte concentrations measured through fluorescence are $10^{6}$ times lower than those of absorption techniques (Liu S et al., 2013).

Fluorescent biosensors use the phenomenon of fluorescence that occurs when an analyte is recognized by biological fluorescent molecules (natural or fluorescent labeled) located in the receptor layer.

The phenomena of fluorescence in immunosensors occur in four typical immunoreaction configurations. They are called: direct, competitive, sandwich and displacement configurations.

In the direct format, an unlabeled antigen bonds with an unlabeled antibody (Borisov \& Wolfbeis, 2008).

In the competitive configuration, an unlabeled antibody interacts with an unlabeled antibody present in the sample (Helder et al., 2002) and fluorescence intensity is proportional to analyte concentration.

In the sandwich format, an antibody is immobilized on the surface and bonds with an antigen present in the sample.

Another fluorescent labeled antibody binds with various antigen epitopes. This generates a fluorescence signal proportional to the amount of antigens in the sample (Cruz et al., 2002).

The displacement configuration is the least common one. It occurs between fluorescent labeled antigens previously bound to an immobilized antibody and an unlabeled antigen. The detection is based on changes in fluorescent intensity (Borisov \& Wolfbeis, 2008).

The phenomenon of fluorescence reflects changes in fluorescent properties of the receptor layer.

This is an emission phenomenon and is a response of fluorophores to excitation by electromagnetic radiation in the visual light wavelength range.

Radiation may be emitted at a shorter, the same or longer wavelength than the excitation wavelength.

When the emission wavelength is longer than the excitation wavelength, it is said that an energy loss occurs and a spectral shift called Stokes shift (Das A et al., 2014).

In fluorescence-based immunosensors, measurements include: variations in fluorescent intensity, energy transfer between donor and acceptor (FRET) or life time.

The variation in fluorescent intensity is the most frequently measured parameter in immunosensors.

This measurement allows the activity of biosensor receptor layer under the effect of analyte binding to be determined (Li et al., 2014). Variations in fluorescent intensity was used for detecting viruses (Jung et al., 2010), disease biomarkers (Zhu et al., 2014; Matveeva et al., 2004; Lee et al., 2010, and immunoglobulins G (Aoyagi et al., 2005).

Energy transfer (FRET) occurs between a donor and acceptor if the distance between them does not exceed $10 \mathrm{~nm}$ and the dipole orientation of both molecules is appropriate (Liu et al., 2013 \& Durick et al., 2001).

The studies of immunosensors by using fluorescent technique and based on measurements of energy transfer between donor and acceptor (Fröster Resonance Energy Transfer) were conducted by Anderson, Grant and Handbury. The measurement of phenytoin (Anderson at al., 1988); detection of troponin $\mathrm{T}$ and I (Grant et al., 2004) were made. This method was used to analyze immunosensor response to theophylline (Handbury et al., 1996). In addition, this method was employed by Heyduk \& Hejduk (2010); Ko \& Grant (2006); Wang et al. (2012) for detecting: pathogenic bacteria, salmonella typhimurium, concentration of albumin in saliva, urine and serum, respectively.

The life time is a fluorophore property that refers to the average duration of the excited state of a fluorophore (i.e. between photon absorption by stimulated emission of radiation and fluorescence emission) (Rae et al., 2009). The fluorescence technique based on this value is called Time Resolved Fluorescence. This technique was used, for example, for detecting ricin (Huang et al., 2015).

Examples of applications of the above fluorescence methods in studies of immunosensors along with analytes to be detected and references are presented in Table 3 .

Taking into account scientific reports in the last two decades related to fluorescence detection methods commonly used in immunosensor studies, it is quite clear that the method based on variations in fluorescent intensity is the most common one, and then the method based on energy transfer (FRET). The method called Time Resolved Fluorescence occupies the last place.

\section{APPLICATIONS OF IMMUNOSENSORS}

When reviewing scientific reports on applications of immunosensors, the following two terms are most frequently used, namely: immunoassay (immunotests) and immunosensor. However, there is a difference between them. In biosensors the receptor layer can be used many times for detection purposes, thus enabling continuous monitoring. For immunoassay, after an immunological 
reaction is completed, and before the next measurement is made, the receptor layer should be regenerated. (Ramirez et al., 2009).

Immunosensors and immunotests are commonly used in environmental protection where there is a need of monitoring of water quality (Long et al., 2008), toxic chemicals, pesticides, chemical weapons (Shankaran et al., 2007), and in food analysis (Tokarskyy \& Marshall, 2008), but they are most often used in medicine (Medyanseva et al., 2001), where blood, urine or saliva samples enable concentrations of morphine, progesterone, estradiol, dopamine, insulin to be determined (Shankaran et al., 2007).

ELISA (Enzyme Linked Immune Sorbent Assay) is the oldest and also the most frequently used immunological test due its low cost and high repeatability. This test was used, among others, to detect malaria (Podder et al., 2015), HIV diagnosis (Igbal et al., 2012 or toxoplasmosis (Rahbari et al., 2012).

\section{SUMMARY}

Biosensors create a highly promising tool allowing fast, low-cost and accurate measurements.

They are commonly used in food analysis, environmental protection, arms industry as well as in medicine, especially in diagnosis.

Optical immunosensors, in particular those based on fluorescence, are frequently used due to their selectivity and sensitivity.

When considering immunosensor development, scientific challenges and future trends, biosensors, especially fluorescent immunosensors become very interesting and open huge opportunities for scientists, engineers and industries.

\section{REFERENCES}

Alvarez S, Li Ch, Chiang C, Shuller I, Sailor M (2009) A label- free porous alumina interferometric immunosensors. ASCnano 3: 33013307. http://dx.doi.org/10.1021/nn900825q.

Aoyagi S, Kudo M (2005) Developement of fluorescencje changebased reagent-less optic immunosensor. Biosensor Bioelectronics 20 , 1680-1684. http://dx.doi.org /10.1016/j.bios.2004.06.041.

Ammarasekera M (2011) Immunoglobulin $E$ in health and disease , Asian Pacific Allergy 1: 12-15. http://dx.doi.org/10.54.5415/apallergy.2011.1.1.12.

Anderson F, Miller F (1988) Optic immunochemical sensor for continuous reversible measurement of phenytoin. Clin Chem 34: 14171421.

Bartoszcze M (2003) Methods of biological weapon threats detection. Przeglad Epidemiologiczny 57: 369-376 (in Polish).

Bhardway V, McGoron A. J (2014) Biosensor technology for chemical and biological toxins: progress and prospects. Photon J Biomed Eng 112: $380-392$.

Bontidean J, Ahlqvist J, Mulchandani A, Chen W, Bae W, Mehra R, Mortani A, Csöregi E (2003) Novel synthetic phytochelatinbased capacitive biosensor for heavy metal ion detection. Biosensors and Bioelectronics 18: 547-553. http://dx.doi.org/10.1016/S09565663(03)00026-5.

Borisov S, Wolfbeis O (2008) Optical biosensors. Chem Rev 108: 423461. http://dx.doi.org/10.1021/cr068105t.

Braden BC, Acqua DW, Esenstein E, Fields BA, Goldbaum AF, Mariuzza RA, Schwarz FP, Ysern X, Poljak RJ (1995) Protein motion and lock and key complementarity in antigen-antibody reactions, Pharmacentica Acta Helvetiae 69: 225-230. http://dx.doi. org/10.1016/0031-6865(94)00046-X.

Burnworth M, Rowan S, Weder Ch (2007) Fluorescent sensors for detection of chemical warfare agents. Chem Eur J 13: 7828-7836. http://dx.doi.org/10.1002/chem.200700720.

Chikkavaveeraiah B, Bhirde A, Morgan N, Eden H, Chen X (2012) Electrochemical immunosensors for detection of cancer protein biomarkers. ACS Nano 6, 6546-6561. 461. http://dx.doi.org/10.1021/ nn3023969.
Chang ML, Cui C, Liu YH, Pei LC, Shao B (2015) Analysis of total immunoglobulin $\mathrm{E}$ and specific immunoglobulin $\mathrm{E}$ of 3,721 patients with allergic disease. Biomedical Reports 3 (4): 573-577. http://dx.doi. org/10.3892/br.2015.455.

Chen Y, Huang X, Shi H, Wang Y (2011) Research progress of piezoelectric immunosensors. Piezoelectricity, Acoustic Waves and Devices Applications (SPAWDA) 2011, Symposium on: 286-289.

Chen X, Jia X, Han J, Ma J, Ma Z (2013) Electrochemical immunosensors for simultaneous detection of multiplex cancer biomarkers based on graphene detection. Biosensors Bioelectronics 50: 356-361. http://dx.doi.org/10.1016/j.bios.2013.06.054.

Cruz H, Rosa C, Abel O (2002) Immunosensors for diagnostic applications Parasitol Res 88: 4-7.

Cynk P, Gaweł E (2012) The application of biosensors in tumor diagnostics. Przeglad Medyczny Uniwersytetu Rzeszowskiego i Narodowego Instytutu Lekón w W arsqawie 3: 373-378 (in Polish).

Das A, Kumar P, Swain S (2014) Recent advances in biosensor based endotoxin detection. Biosensor Bioelectronics 51: 62-75. http://dx.doi. org/10.1016/j.bios.2013.07.020.

Davies D, Sheriff S, Padlan E (1988) Antibody-Antigen Complexes. I Biol Chem 263: 10541-10544.

Durick K, Negulescu P (2001) Cellullar biosensors for drug discovery. Biosensors Bioelectonics 16: 587-592. http://dx.doi.org/10.1016/S09565663(01)00173-7.

Edholm E, Bengten E, Wilson M (2011) Insighs into the function of IgD. Develop Comp Immunol 35: 1309-1316. http://dx.doi. org/10.1016/j.dci.2011.03.002.

Ehrenstein M, Notley C (2010) The importance of natural IgM: scavenger, protector and regulator. Nature Reviews Immunol 10: 778-786. http://dx.doi.org/10.1038/nri2849.

Endo T, Okuyama A, Matsubara Y, Nishi K, Kobayashi M, Yamamura S, Morita Y, Takamura Y, Mizukami H, Tamiva E, Fluorescence-based assay with enzyme amplification on a microflow immunosensor chip for monitoring coplanar polychlorinated piphenyls. Analytica Chimica Acta 531: 7-13. http://dx.doi.org/10.1016/j. aca.2004.08.077.

Gabig-Cimińska M, Holmgren A, Andersen H, Bundvig Barken K, Wümpelmann, Albers J, Hintsche R, Breintenstein A, Neubauer P, Los M, Czyz A, Węgrzyn G, Silfversparre G, Jürgen B, Sweder T, Enfors S-O (2004) Electric chips for rapid detection and quantification of nucleic acids. Biosensors Bioelectronics 19: 537-546. http:// dx.doi.org/10.1016/S0956-5663(03)00273-2.

Gabig-Cimińska M, Liu Y, Ehnfors, S-O (2005), Gene-based identification of bacterial colonies with electric chip. Anal Biochem 11: $270-$ 276. http://dx.doi.org/10.1016/j.ab.2005.07.024.

Geisberger R, Lamers M, Achatz G (2006) The riddle of the dual expression of $\operatorname{IgM}$ and IgD. Immunology 118: 429-437. http://dx.doi. org/10.1111/j.1365-2567.2006.02386.x.

Grand S, Fryer M, Lichlyter D, Saykan O (2004) Investigation of a FRET Immunosensor technique for the detection of troporin $\mathrm{T}$ and I. Sensors Lett 2: 58-63.

Griffits G, Lucocq J,M (2014) Antibodies for immunolebeling by light and electron microscopynot for the faint hearted. Histochem Cell Biol 142: 347-360. http://dx.doi.org/10.1007/s00418-014-1263-5.

Gołąb J, Jakubiński M, Lasek W, Stokłosa T (2013) Immunology (new edition), Wydawnictwo Naukowe PWN (in Polish).

Gong F, Li D, Yang R, Wei J, Cao Z, Tan S, Tan F (2009) Cyanidinhorseradish peroxidase-hydroperoxide reaction system and its application in enzyme-linked immunosensing assays. Science China Ser B. Chem 52: 1142-1147. http://dx.doi.org/10.1007/s11426-009-0037-8.

Grönwall C, Vas J, Silverman G (2012) Protective roles of natural IgM anibodies. Front Immunol 1-10. http://dx.doi.org/10.3389/ fimmu.2012.00066.

Guo L, Guo Z, Zheng B, Han S (2010) IgD BCR-mediated signals do not hale protective roles in negative selection of autoreactive $B$ cells in lpr mice. I Immunol 184: 143.29.

Hamilton RG, MacGlashan DW Jr, Saini SS (2010) IgE antibodyspecific activity in human allergic disease. Immunologic Research 47: 273-284. http://dx.doi.org/10.1007/s12026-009-8160-3.

Handbury M, Miller W, Harris (1996) Antibody characteristics for continuous response fiber immunosensor for theophyline. Biosensor Bioelectronics 11: 1129-1138. http://dx.doi.org/10.1016/09565663(96)82335-9.

Heyduk E, Hejduk T (2010) Fluorescent homogenous immunosensors for detecting pathogenic bacteria. Anal Biochem 396: 298-303. http://dx.doi.org/10.1016/j.ab.2009.09.039.

Hjelhold A, Christainsen G, Sorensen U, BirkelungS (2013) IgG subclass profiles in normal human sera of antibodies specific to five kinds of microbial antigens, Pathogens and Disease 67: 206-213. http://dx.doi.org/10.1111/2049-632X.12034.

Hnaiein M, Hassen W, Abdelghani A, Fournier-Wirth C, Coste J, Bessueille FLeonard D, Jaffrezic-Renault N (2008) A conductometric immunosensor based on functionalized magnetie nanoparticles for E. coli detection. Electrochemistry Comunications 10: 1152-1154. http://dx.doi.org/10.1016/j.elecom.2008.04.009. 
Huang Y, Chen X, Wu S, Duan N, Yu Y, Wang Z (2015) Homogenous time resolved fluorescence assay for the detection of ricin using a aptamer immobilized on europium-doped $\mathrm{KGdF}_{4}$ nanoparticles and grapheme oxide a a quencher. Microchimica Acta 182: 10351043. http://dx.doi.org/10.1007/s00604-014-1422-3.

Igbal S, Solomon S, Murugavel K, Salomon SS, Blakrishnan P (2012). Evaluation of two indigenous rapid and two ELISA assays for diagnosis of HIV infection India. Indian Journal of Medical Microbiology 30: 397-402. http://dx.doi.org/10.4103/0255-0857.103758.

Ivnitski D, Abdel-Hamid I, Atanasov P, Wilkins E (1999) Biosensors for detection pathogenic bacteria Biosensor Bioelectronics 14: 599-624.

Jaramillo M, Montagut Y, Montaya A, Robledo J, Marin P, Betancur J, Moreno M, Pabon E, Torres R (2013) Design of piezoelectric immunosensor for tuberculosis biomarker detection. Health Care Exchanges (PAHCE 2013): 1-7. http://dx.doi.org/ 10.1109/PAHCE.2013.6568332.

Jung J, Cheon D, Liv F, Leek B, Seo T (2010)A grapheme oxide based immuno-biosensor for pathogen detection. Angew Chem Int Ed Eng 49: 5708-5711. http://dx.doi.org/10.1002/anie.201001428.

Justino C, Rocha-Santos T, Duarte A (2010) Review of analytical figures of merit of sensors and biosensors in clinical applications. Trends Anal Chem 29: 1172-1183. http://dx.doi.org/ 10.1016/j. trac.2010.07.008

Kamtekar S, Pande R, Ayyagari M, Marx K, Kaplan J, Kumar J, Tripathy S (1995) A chemiluminescence-based biosensors for metal ion detection. Materials Science and Engineering C3 (1995): 79-83.

Karotkaya E (2014) Biosensors: design, classification and applications in the food industry. Food and Raw Materials 2: 161-171. http://dx. doi.org/10.12737/5476.

Kaveri S, Silverman G, Bayry J (2012) Natural IgM in immune equilibrium and harnessing their therapeutic potential. I Immunol 188: 939-945. http://dx.doi.org/10.4049/jimmunol.1102107.

Kłos-Witkowska (2015) Fluorescent biosensor based on enzyme for environmental, clinical and industry applicatons. Polish $J$ Environ Studies 24: 19-25. http://dx.doi.org/10.15244/pjoes/28352.

Ko S, Grant S (2006) A novel FRET-based optical fiber biosensor for rapid detection of Salmonella typhimurium. Biosensors Bioelectronics 21: 1283-1290. http://dx.doi.org/10.1016/j.bios.2005.05.017.

Kulkarni S, Kalpana J, Karve M, Damle K (2011) Development of fluorescencje based biosensor for estimation heavy metal ions. International Conference on Biochemistry and Bioinformatics IPCBEE vol 5: 443-445.

Kulshrestha R, Srinivasa T, Biswas J (2013) Role of immunoglobulin G and A in periodontitix. J Pure Applied Microbiol 7: 673-676.

Kumar A (2000) Biosensors based on piezoelectric crystal detectors: theory and applications. JOM-e $\mathbf{5 2}$.

Leckband D, Kuhl T, Wang H, Müller W, Herron J, Ringisdorf (2000) Force probe measurement of antibody-antigen ineraction. Methods 20: 329-340. http://dx.doi.org/10.1006/meth.1999.0926.

Lee H, Lee S, Yukusawa T, Raqman-Azcon J, Mizutani F, Ino K, Shiku H, Matsue T (2010). Rapid and simple immunosensing system for simultaneous detection of tumor markers based on negative dielectrophoretic manipulation of microparticles. Talanta 81: 657-663. http://dx.doi.org/10.1016/j.talanta.2009.12.058.

Leonard P, Hearty S, Brennan J, Dunne L, Quinn J, Chakraborty T, O'Kennedy R (2003) Advances in biosensors for detection of pathogens in food and water. Ensyme Microbial Technol 32: 3-13.

Li Y, Hong M, Qiu B, Lin Z, Chen Y, Cai Z, Chen G (2014) Highly sensitive fluorescent immunosensor for detection of influenza virus based on Ag autocatalysis. Biosensors Bioelectronics 54: 358-364. http://dx.doi.org/10.1016/j.bios.2013.10.045.

Liu S, Zhen Z, Li X (2013) Advances in pesticide biosensors: current status, challenges and future perspectives. Anal Bioanal Chem 405: 63-90. http://dx.doi.org/10.1007/s00216-012-6299-6.

Long F, He, Shi H, Zhu A (2008) Developement of evanescent wale all-fiber immunosensor for enviromental water analysis. Biosensors Bioelectronics 23: 952-958. http://dx.doi.org/10.1016/j.bios.2007.09.013.

Majkowska-Skrobek G, Augustyniak D (2004) The structure and function of human IgA subclases. Kosmos 53: 155-165 (in Polish).

Matveeva E, Gryczynski Z, Malicka J, Gryczynski J, Lakowicz J (2004) Metal-enhanced fluorescet biomarkers for cardiac risk assessment. Proc SPIE Int Soc Opt Eng 5327: 45-52. http://dx.doi. org/10.1117/12.530091.

Mazher-Iqbal M, Desmulliez M (2011). Lab-on-a-chip based immunosensor principles and technologies for detection of cardiac biomarkers: a review. Lab on a Chip 11: 569-595. http://dx.doi. org/10.1039/COLC00204F.

Medyanseva E, Khaldeeva E, Budnikov G (2001) Immunosensors in biology and medicine: analytical capabilities, problems and prospects. I Anal Chem 56: 1015-1031. http://dx.doi. org/10.1023/A:1012345025093.

Meng X, Wei J, Ren X, Ren J, Tang F (2013) A simple and sensitive fluorescence biosensor for detection of organophosphorus pesticides using $\mathrm{H}_{2} \mathrm{O}_{2}$-sensitive quantun dots/bi enzyme. Biosens Bioelectron 47: 402-407. http://dx.doi.org/10.1016/j.bios.2013.03.053.
Moina C, Ybarra G (2012) Advances in Immunoassay Technology, Chapter 4, Fundaments and application of immunosensors. Norman HL, Chiu, Christopoulos TK 66-80.

Monosik R, Stredansky M, Sturdik E (2012) Biosensors-classification, characterization and new trends. Acta Chemica Slovenica 5: 109-120. http://dx.doi.org/10.2478/v10188-012-0017-z.

Mostafa G (2010) Electrochemical biosensors for detection of pesticides. The Open Electrochemistry J 2: 22-42.

Mujika M, Arana S, Castano E, Tijero M, Vilares R, Ruona-Lopez J, Cruz A, Sainz L, Berganza J (2009) Magnetoresistative immunosensors for the detection of Ershelica coli 0157: H7 including microfluidic network. Biosensors Bioelectronics 24: 1253-1258. http://dx.doi. org/10.1016/j.bios.2008.07.024.

Nepper-Christensen S, Backer V, DuBuske LM, Nolte H (2003) In vitro diagnostic evaluation of patients with inhalant allergies: summary of probability outcomes comparing results of CLA- and CAP-specific immunoglobulin E test systems. Allergy and Asthma Proceedings 24: 253-258.

Nidzworski D, Pranszke P, Grudniewska M, Król E, Gromadzka B (2014) Universal biosensors for detection if influenza virus. Biosensor Bioelectronics 59: 239-242. http://dx.doi.org/10.1016/j. bios.2014.03.050.

Oh B-K, Kim Y-K, Lee W, Baea YM, Won Hong Leea WH, JeongWoo Choia J-W (2003) Immunosensor for detection of Legionella pneumophila using surfach plazmon resonance. Biosensors Bioelectronics 18: 605-611. doi:10.1016/S0956-5663(03)00032-0.

Oh B-K, Kim Y-K, Park K, Lee W, Choi J (2004) Surface plasmon resonance immunosensors for the detection of Salmonella typhimurium. Biosensors Bioelectron 19: 1497-1504. http://dx.doi.org/10.1016/j. bios.2003.12.009.

Jyoung Jy, Hong SH, Lee W, Choi JW (2006) Immunosensor for detection of legionella pneumophila using surface plasmon resonance Biosensors Bioelectron 21: 2315-2319. http://dx.doi.org/10.1016/j. bios.2005.10.015.

Pattnaik P (2005) Surface Plasmon Resonance (SPR). Application in understanding receptor-ligant interaction. Appl Biochem Biotechnol 126: 79-92.

Podbierska H (2011) Biomedical Optics selected issues, chapter 11. Oficyna Wydawnicza Politechniki Wrocławskiej, 295-313 (in Polish).

Polder M, Khanum H, Elami R, Mohan A, Mohiuddin M, Alam M (2015) Comparison of New ELISA kit (Recombisia Malaria AB Test with Microscopic-Detection of Malaria. Modern Biotechniques and Biotechnology 237-243

Rahbari A, Keshavarz H, Shojaee S, Rezaeian M (2012) IgG avidity ELISA test for diagnosis of acute toxoplasmosis in humans. Korean J Parasitol 50: 99-102. http://dx.doi.org/10.3347/kjp.2012.50.2.99.

Reverberi R, Reverberi L (2007) Fasctor affecting the antygenantibody reaction. Blond Transfus 5: 227-240. http://dx.doi. org/10.2450/2007.0047-07.

Rosenwasser LJ (2011) Mechanisms of IgE Inflammation. Current Allergy and Asthma Reports 11: 178-83. http://dx.doi.org/10.1007/ s11882-011-0179-6.

Quchida R, Mori H, Hase K, Takatsu H, Kurosaki T, Tokuhisa T, Ohno H, Wang J (2012) Critical role of the IgM Fc receptor in IgM homeostasis, B-cell survival and humoral immune responses. Proc Natl Acad Sci USA 109: 2699-2706. http://dx.doi.org/10.1073/ pnas.1210706109.

Que X, Tang D, Lu X, Tang D (2014) Gold nanocatalyst-based immunosensing strategy accompanying catalytic reduction of 4- nitrophenol for sensitive monitoring of chloramphenicol residue. Analytica Chimica Acta 830: 42-48. http://dx.doi.org/10.1016/j. aca.2014.04.051.

Rae B, Muir K, Gong Z, McKendry J, Girkin J, Gu E, Rendshaw D, Dawson M, Henderson R (2009) A CMOS time-resolved fluoresce lifetime analysis micro-system. Sensors 9: 9255-9274. http://dx.doi. org/10.3390/s91109255.

Rana J, Jindal J, Beniwal V, Chhokar V (2010) Utility biosensors for applications in agriculture. J Am Sci 6: 353-375.

Ramirez B, Salgado A, Valdman B (2009) The evolution and development of immunosensors for health and environmental monitoring: problems and perspectives. Brazilian J Chem Eng 26: 227-229.

Sapsford K, Shubin Y, Delehanty J, Golden J, Taitt C, Shriver-Lake L, Ligler F (2004) Fluorescence- based array biosensors for detection of biohazards. J Appl Microbiol 96: 47-58. http://dx.doi. org/10.1046/j.1365-2672.2003.02115.x.

Sassolas A, Prieto-Simon B, Marty J (2012) Biosensors for pesticide detection: new trends. Am J Anal Chemi 3: 210-232. http://dx.doi. org/10.4236/ajac.2012.33030.

Shankaran D, Gobi H, Miura N (2007) Recent advencements in surface plasmon resonance immunosensor for detection of small molecules of biomedical, food, enviromnetal interst. Sensors and Actuators B: Chemical 121: 158-177. http://dx.doi.org/10.1016/j.snb.2006.09.014.

Shruthi GS, Amitha CV, Blessy-Baby M (2014) Biosensors: a modern day achivement. J Instrument Technol 2: 26-39. http://dx.doi. org/10.12691/jit-2-1-5. 
Snoeck V. Peters I, Cox E (2006) The IgA system: a comparison of structure and function in different species. Veterinary Res 37: 455467.

Soper S, Brown K, Ellington A, Frazier B, Garcia- Manero G, Gau V, Gutman S, Hayes D, Korte B, Landers J, Larson D, Ligler F, Majumdar A, Mascini M, Nolte D, Rosenzweig Z, Wang J, Wilson D (2006) Poin-of-care biosensor systems for cancer prognostics. Biosensor Bioelectronics 21: 1932-1942. http://dx.doi.org/10.1016/j. bios.2006.01.006.

Szekacs A, Adanyi N, Szekacs I, Szendro I (2009) Optical wavequite light-mode spectroscopy immunosensors for environmental monitoring. Apply Opt 48: 151-158. http://dx.doi.org/ 10.1364/ AO.48.00B151.

Thevenot D, Toht K, Dust R, Wilson G (1999) Electorchemical biosensors:recommended definitions and classification (Technical Report). Pure Appl Chem 71: 2333-2348.

Thusu R (2010) Medical strong growth predicted for biosensors market Frost \& Sullivan Report. www.sensorsmag.com.

Tokarskyy O, Marshall D (2008) Immunosensors for rapid detection of Erchelica coli 0157:H7 - perspective for use in the meat processing industry. Food Microbilogy 25: 1-12. http://dx.doi.org/10.1016/j. fm.2007.07.005.

Tothill I (2009) Biosensors for cancer marker diagnosis. Seminars in Cell \& Developemental Biology 20: 55-62. http://dx.doi.org/10.1016/j. semcdb.2009.01.015.

Unzu C, Melero I, Morales-Kastresana A, Sampedro A, Serrano-Mendioroz I, Azpilikueta A,Ochoa M, Duibrot J, Martinez-Anso E, Fontanellas A (2014) Innate Functions of Immunoglobulin M Lessen Liver Gene Transfer with Helper-Dependent Adenovirus. PLoS ONE 9: 85432. doi: 10.1371/journal.pone.0085432.
Wang R, Tian L, Chang Y (2012) A homogeneus fluorescent sensor for human serum albumin. J Pharm Biomed Anal 63: 165-169. http://dx.doi.org/ 10.1016/j.jpba.2011.12.035.

Woof J, Kerr M (2006) The function of immunoglobulin A in immunity. J Pathol 208 (2) 270-282 http://dx.doi.org/10.1002/path.1877.

Vidarsson G, Dekkers G, Rispens T (2014) IgG subclasses and allotypes: from structure to effectors functions. Frontiers in Immunology 5: 1-17. http://dx.doi.org/10.3389/fimmu.2014.00520.

Vo-Dinh T, Cullum B (2000) Biosensors and biochips advances in biological and medicine diagnostics Fresenius J Anal Chem 366: 540-551. http://dx.doi.org/10.1007/s002160051549.

Xu J, Suarez D, Gottfried D (2007) Detection of avarian influenza virus using an interferometric biosensors. Anal Bioanal Chem 384: 1193-1199. http://dx.doi.org/10.1007/s00216-007-1525-3.

Yang M, Javadi A, Gong S (2011) Sensitive electrochemical immunosensor for the detection of cancer biomarker using quantum dot functionalized grapheme sheets as labels. Sensors and Actuators B: Chemical 155: 357-360. http://dx.doi.org/10.1016/j.snb.2010.11.055.

Ying Z, Yaonyao C, Xia S, Xiangyou W (2013) Amperometric immunosensors for carbofuran detection based on MWCNTS/GS-PEIAuu and AuNPS-antibody conjugate. Sensors 13: 5286-5301. http:// dx.doi.org/10.3390/s130405286.

Zhang Y, Yang D, Weng L, Wang L (2013) Early lung cancer diagnosis by biosensors. Int J Mol Sci 14: 15479-15509. http://dx.doi. org/10.3390/ijms140815479.

Zhu Y, Peng J, Jiang L, Zhu J-J (2014) Fluorescent immunosensor based on CuS nanoparticles for sensitive detection cancer biomarker. Analyst 139: 649-655. http://dx.doi.org/10.1039/C3AN01987J. 